\title{
Effect of Spacing and Training on Vegetative Growth Characteristics and Yield of Tomato (Solanum lycopersicum L.) Grown in Polyhouse
}

\author{
Satveer Yadav, K.D. Ameta*, S.K. Sharma, R.B. Dubey, R.S. Rathore, \\ Hareram Kumar and V.K. Kapuriya \\ Rajasthan College of Agriculture, Maharana Pratap University of Agriculture and Technology, \\ Udaipur 313001, Rajasthan, India \\ *Corresponding author
}

\section{A B S T R A C T}

An experiment was carried out to study the effect of spacing and training on vegetative growth characteristics and yield of tomato under polyhouse. The experiment was comprised of four levels of spacing and three levels of training with Factorial Completely Randomized Design. The experimental results revealed that maximum plant height $(241.18 \mathrm{~cm})$, stem diameter $(7.42 \mathrm{~cm})$, number of branches per plant $(26.67)$, leaf area $\left(325.84 \mathrm{~cm}^{2}\right)$, number of clusters per plant (18.63), number of fruits per cluster (6.31), number of fruits per plant (112.44), fruit weight $(106.93 \mathrm{~g})$, volume of fruit $(110.70 \mathrm{cc})$, specific gravity $\left(0.97 \mathrm{gcm}^{3}\right)$ and yield per plant $(12.07 \mathrm{~kg})$ were recorded on wider spacing $\mathrm{S}_{4}(60 \times 60 \mathrm{~cm})$. The maximum stem diameter $(7.36 \mathrm{~cm})$, number of branches per plant (24.53), number of clusters per plant (15.93), total yield per plant $(8.48 \mathrm{~kg})$ and yield per square meter $\left(20.96 \mathrm{~kg}\right.$ ) were exhibited by $\mathrm{T}_{3}$ (triple stem training). The maximum yield per square meter was observed in interaction $\mathrm{S}_{2} \mathrm{~T}_{3}(45 \mathrm{x} 45 \mathrm{~cm}$, triple stem). while number of branches per plant (30.33), number of clusters per plant (19.67), number of fruits per cluster (6.77), number of fruits per plant (125.87) and total yield per plant $(12.88 \mathrm{~kg}$ ) were observed in treatment combination $\mathrm{S}_{4} \mathrm{~T}_{2}(60 \times 60 \mathrm{~cm}$, double stem training).

\section{Introduction}

Tomato (Solanum lycopersicum L.) is one of the most important vegetable crops in the India. It belongs to family Solanaceae with diploid chromosome number $(2 \mathrm{n}=24)$ and is a typical self-pollinated day neutral plant. Tomato has originated from South America (Mexico and Peru). In tomato there are two types of growth habit have been found viz., determinate (generally grown under open field condition) and indeterminate (normally grown under poly house condition). It is cultivated in both temperate and tropical regions of the world. It is consumed in a various ways like fresh in salads and sandwiches, cooked or processed in ketchup, sauces, paste, puree, juices or dried powder. Tomato plays an important role in human nutrition by providing essential amino acids, vitamins and minerals (Sainju et al., 2003) and it is considered a protective food because of its particular nutritive value, as it provides important nutrients such as lycopene, betacarotene, flavonoids, vitamin ' $\mathrm{C}$ ' and hydroxycinnamic acid derivatives. Furthermore, this crop has achieved tremendous popularity especially in recent 
years with the discovery of lycopene's antioxidative activities and anti-cancer functions (Wu et al., 2011; Raiola et al., 2014). Edible portion of tomato contains energy $18 \mathrm{kcal}$, protein $0.95 \mathrm{~g}$, fat $0.11 \mathrm{~g}$, carbohydrate 4.01 $\mathrm{g}$, total sugar $2.49 \mathrm{~g}$, Ca $11.0 \mathrm{mg}$, Fe $0.68 \mathrm{mg}$, $\mathrm{Mg} 9.0 \mathrm{mg}$, P $28.0 \mathrm{mg}, \mathrm{K} 218.0 \mathrm{mg}$, Na 11.0 $\mathrm{mg}, \mathrm{Zn} 0.14 \mathrm{mg}$, thiamin $0.036 \mathrm{mg}$, riboflavin $0.022 \mathrm{mg}$, carotene (Vit. A) $320 \mathrm{IU}$, vitamin B $60.079 \mathrm{mg}$, ascorbic acid 31mg per $100 \mathrm{~g}$ pulp of fruit. The cultivation of vegetables under polyhouse is increasing in the state. In polyhouse, microclimate surrounding the plant is controlled partially or fully, as per the requirement of the plant species (Mishra et al., 2010). In this study the main emphasis was given on appropriate cultural practices such as plant densities and training systems in order to enhance the production per unit area by utilizing the available space and utilization of the resources.

\section{Materials and Methods}

To assess effect of spacing and training on vegetative growth characteristics and yield of tomato grown under polyhouse an experiment was laid out at Hi-Tech Horticulture Unit, Department of Horticulture, Rajasthan College of Agriculture, Udaipur (Rajasthan) during August, 2015 to March, 2016. The size of the polyhouse was $28 \mathrm{~m} \times 32 \mathrm{~m}$ (896sq.m) covered with aluminate sheet and ultra violet stabilized low density polyethylene sheet having 200 micron thickness. The experiment was comprised of four levels of spacing, i.e., $45 \mathrm{~cm} \times 30 \mathrm{~cm}\left(\mathrm{~S}_{1}\right), 45 \mathrm{~cm} \times 45 \mathrm{~cm}\left(\mathrm{~S}_{2}\right), 45$ $\mathrm{cm} \times 60 \mathrm{~cm}\left(\mathrm{~S}_{3}\right)$ and $60 \mathrm{~cm} \times 60 \mathrm{~cm}\left(\mathrm{~S}_{4}\right)$ and three levels of training, viz., single stem $\left(\mathrm{T}_{1}\right)$, double stem $\left(\mathrm{T}_{2}\right)$, triple stem $\left(\mathrm{T}_{3}\right)$. The seedlings were raised on soil-less media (mixture of vermiculite, perlite and cocopit) in plug tray having cells of 2" in size. Four week old seedlings at 4-5 true leaf stage were transplanted at $45 \times 30 \mathrm{~cm}, 45 \times 45 \mathrm{~cm}, 45 \mathrm{x}$ $60 \mathrm{~cm}$ and $60 \times 60 \mathrm{~cm}$ according to different treatment combinations. Beds were irrigated when necessary during the growing season. Fertilizers were applied @ 200: 120: $120 \mathrm{~kg}$ NPK ha ${ }^{-1}$, respectively along with micronutrient for raising healthy crop. All the management practices including hoeing; weeding and other horticultural operation were performed. Insecticide and fungicide spray were applied whenever it appeared necessary throughout the growing season. Plants were vertically trained with single stem $\left(T_{1}\right)$, double stem $\left(T_{2}\right)$, triple stem $\left(T_{3}\right)$ per plants as per treatment combinations. The observations on plant height $(\mathrm{cm})$, stem diameter $(\mathrm{cm})$, number of branches per plant, leaf area $\left(\mathrm{cm}^{2}\right)$, days to first harvesting, number of clusters per plant, number of fruits per cluster, number of fruits per plant, fruit weight $(\mathrm{g})$, fruit diameter $(\mathrm{cm})$, volume of fruit (cc), specific gravity $\left(\mathrm{g} / \mathrm{cm}^{3}\right)$, total yield per plant $(\mathrm{kg})$ and yield per square meter $(\mathrm{kg})$ were recorded from five randomly selected plants of each replication.

The plant height was measured in centimeter from the ground level to extreme growing tip of the main stem with the help of meter scale at the time of final harvest. Stem diameter was measured in centimeter at $2 \mathrm{~cm}$ above the ground level of plant and diameter of stem was measured with the help of vernier calipers at the stage of final harvesting. Total number of branches of individual plants was counted at the stage of final harvesting. Leaf area per plant was determined using leaf area meter, LICOR-3100 USA. Leaf area was measured at the time of final harvesting and expressed as $\mathrm{cm}^{2}$. The days from the date of transplanting to the date of first harvesting in each treatment were recorded. The difference of the date of transplanting and date of first harvesting was calculated for the number of days required for harvesting. Total number of clusters per plant was counted on plants and averages were computed. Total number of fruits per cluster was counted from randomly 
selected 10 clusters on all the five tagged plant and average was calculated. The number of fruits was counted separately on the five randomly selected plants on each date of harvest till all the fruits were harvested. Then average number of fruits per plant was calculated after dividing total number of fruit by five. Randomly selected five fruits in each treatment were weighed with the help of digital balance and the mean weight of fruit was calculated and expressed in gram. Same five fruits were used for measuring fruit diameter. The diameter of the fruit was measured with the help of vernier callipers in centimeter and average was calculated. Same five fruits which were used for recording weight of fruits were used for measuring fruit volume. Volume was measured by water displacement method. For this purpose, fruits were dipped in a full filled jar of water and the water displaced by the fruits was collected and measured by graduated glass jar and average volume of fruit was calculated. Specific gravity of the fruit was worked out by dividing the weight of the fruit by the volume of the same fruit and was expressed as gram per cubic centimeter. The fruits harvested from five tagged plants were weighed separately with the help of digital balance on each harvest and sum total of each harvesting was computed for getting total yield per plant and expressed in $\mathrm{kg}$. The yield of fruits per square meter was calculated by multiplying the average yield of plant and number of plants per square meter and expressed in kilogram per square meter.

\section{Results and Discussion}

Data (Table-1) reveled that maximum plant height $(241.18 \mathrm{~cm})$, stem diameter $(7.42 \mathrm{~cm})$, number of branches per plant (26.67) and leaf area $\left(325.84 \mathrm{~cm}^{2}\right)$ were recorded at widest spacing i.e. treatment $\mathrm{S}_{4}(60 \mathrm{~cm} \times 60 \mathrm{~cm})$ compared to others. This may be due to the availability of more space for individual plant growth, more leaf area, ample sun light and aeration under wider spacing. These findings were in conformity with the work of Bhattarai et al., (2015) and Singh and Kumar (2005) in cherry tomato. Among the method of training, the maximum stem diameter $(7.36 \mathrm{~cm})$ and number of branches per plant (24.53) were recorded in treatment $\mathrm{T}_{3}$ (triple stem training). These results are in accordance with the findings of Jovicich et al., (1998) in sweet pepper grown in polyhouse. While maximum leaf area $\left(319.72 \mathrm{~cm}^{2}\right)$ was recorded in treatment $\mathrm{T}_{1}$ (single stem), the lowest day to first harvesting was also recorded in treatment $\mathrm{T}_{1}$ (single stem). The present results are supported by the findings of Hesami et al., (2012) in semi determinate tomato. Among the treatment combinations, maximum number of branches per plant (30.33) was observed in $\mathrm{S}_{4} \mathrm{~T}_{3}(60 \mathrm{~cm} \times 60 \mathrm{~cm}$ and triple stem), while lowest days to first harvesting (83.00) was observed in $\mathrm{S}_{1} \mathrm{~T}_{1}(45 \mathrm{~cm} \times 30 \mathrm{~cm}$ and single stem). Similar results were also recorded by Ara et al., (2007) in tomato.

The plant spacing significantly influenced yield attributed characters in tomato. Data (Table-2) revealed that maximum number of clusters per plant (18.63) and number of fruits per plant (112.44) was reported at widest spacing, $S_{4}(60 \mathrm{~cm} \times 60 \mathrm{~cm})$ as compared to lowest in $\mathrm{S}_{1}(45 \mathrm{~cm} \times 30 \mathrm{~cm})$. This might be due to more fruit set, more photosynthesis as it produces more plant height at wider spacing. Similar trend was observed by Mantur and Patil (2008), Bhattarai et al., (2015) and Rajendra et al., (2013) in tomato. Maximum number of fruits per cluster (6.31) at wider spacing $S_{4}(60 \mathrm{~cm} \times 60 \mathrm{~cm})$ and minimum in close spacing $(45 \mathrm{~cm} \times 30 \mathrm{~cm})$. These findings are in accordance with the findings of Rajendra et al., (2013) in tomato and Singh and Kumar (2005) in cherry tomato. The maximum fruit weight $(106.93 \mathrm{~g})$ and yield per plant $(12.07 \mathrm{~kg})$ was observed at widest spacing treatment, $S_{4}(60 \mathrm{~cm} \times 60 \mathrm{~cm})$. 
Table.1 Effect of spacing and training on plant height, stem diameter, number of branches per plant, leaf area, days to first harvesting in polyhouse grown tomato

\begin{tabular}{|c|c|c|c|c|c|}
\hline Treatment & $\begin{array}{l}\text { Plant height } \\
(\mathrm{cm})\end{array}$ & $\begin{array}{c}\text { Stem } \\
\text { diameter } \\
(\mathrm{cm})\end{array}$ & $\begin{array}{c}\text { Number of } \\
\text { branches per } \\
\text { plant }\end{array}$ & $\begin{array}{l}\text { Leaf area } \\
\left(\mathrm{cm}^{2}\right)\end{array}$ & $\begin{array}{c}\text { Days to } \\
\text { first } \\
\text { harvesting }\end{array}$ \\
\hline \multicolumn{6}{|l|}{ Spacing (S) } \\
\hline $\mathrm{S}_{1}(45 \times 30 \mathrm{~cm})$ & 188.38 & 6.86 & 16.64 & 302.23 & 84.56 \\
\hline $\mathrm{S}_{2}(45 \times 45 \mathrm{~cm})$ & 217.70 & 7.14 & 21.16 & 313.09 & 86.33 \\
\hline $\mathrm{S}_{3}(45 \times 60 \mathrm{~cm})$ & 235.90 & 7.25 & 24.02 & 318.07 & 85.11 \\
\hline $\mathrm{S}_{4}(60 \times 60 \mathrm{~cm})$ & 241.18 & 7.42 & 26.67 & 325.84 & 85.78 \\
\hline $\mathrm{SEm} \pm$ & 5.197 & 0.062 & 0.144 & 1.449 & 0.617 \\
\hline $\mathrm{CD}$ at $5 \%$ & 15.169 & 0.180 & 0.421 & 4.229 & NS \\
\hline \multicolumn{6}{|l|}{ Training (T) } \\
\hline $\mathrm{T}_{1}$ & 229.06 & 6.97 & 18.63 & 319.72 & 84.33 \\
\hline $\mathrm{T}_{2}$ & 215.83 & 7.18 & 23.20 & 317.25 & 86.25 \\
\hline $\mathrm{T}_{3}$ & 217.48 & 7.36 & 24.53 & 307.46 & 85.75 \\
\hline SEm \pm & 4.501 & 0.053 & 0.125 & 1.255 & 0.534 \\
\hline $\mathrm{CD}$ at $5 \%$ & NS & 0.156 & 0.364 & 3.663 & 1.560 \\
\hline \multicolumn{6}{|c|}{ Interaction $(S \times T$} \\
\hline $\mathrm{S}_{1} \mathrm{~T}_{1}$ & 202.54 & 6.55 & 15.00 & 306.71 & 83.00 \\
\hline $\mathrm{S}_{1} \mathrm{~T}_{2}$ & 166.11 & 6.79 & 17.07 & 304.07 & 86.00 \\
\hline $\mathrm{S}_{1} \mathrm{~T}_{3}$ & 196.50 & 7.23 & 17.87 & 295.92 & 84.67 \\
\hline $\mathrm{S}_{2} \mathrm{~T}_{1}$ & 226.67 & 6.99 & 18.80 & 316.69 & 87.00 \\
\hline $\mathrm{S}_{2} \mathrm{~T}_{2}$ & 218.74 & 7.19 & 21.73 & 315.86 & 86.00 \\
\hline $\mathrm{S}_{2} \mathrm{~T}_{3}$ & 207.67 & 7.26 & 22.93 & 306.71 & 86.00 \\
\hline $\mathrm{S}_{3} \mathrm{~T}_{1}$ & 240.65 & 7.08 & 20.07 & 323.28 & 84.33 \\
\hline $\mathrm{S}_{3} \mathrm{~T}_{2}$ & 234.97 & 7.32 & 25.00 & 318.09 & 84.00 \\
\hline $\mathrm{S}_{3} \mathrm{~T}_{3}$ & 232.08 & 7.36 & 27.00 & 312.83 & 87.00 \\
\hline $\mathrm{S}_{4} \mathrm{~T}_{1}$ & 246.40 & 7.26 & 20.67 & 332.18 & 83.00 \\
\hline $\mathrm{S}_{4} \mathrm{~T}_{2}$ & 243.48 & 7.42 & 29.00 & 330.97 & 89.00 \\
\hline $\mathrm{S}_{4} \mathrm{~T}_{3}$ & 233.67 & 7.59 & 30.33 & 314.38 & 85.33 \\
\hline SEm \pm & 9.001 & 0.107 & 0.250 & 2.510 & 1.069 \\
\hline $\mathrm{CD}$ at $5 \%$ & NS & NS & 0.7290 & NS & 3.1202 \\
\hline
\end{tabular}


Table.2 Effect of spacing and training on number of clusters per plant, number of fruits per cluster, number of fruits per, fruit weight, fruit diameter, volume of fruit, specific gravity, total yield per plant and yield per square meter in polyhouse grown tomato

\begin{tabular}{|c|c|c|c|c|c|c|c|c|c|}
\hline Treatment & $\begin{array}{l}\text { Number } \\
\text { of } \\
\text { clusters } \\
\text { per } \\
\text { plant }\end{array}$ & $\begin{array}{l}\text { Number } \\
\text { of fruits } \\
\text { per } \\
\text { cluster }\end{array}$ & $\begin{array}{c}\text { Number } \\
\text { of fruits } \\
\text { per } \\
\text { plant }\end{array}$ & $\begin{array}{l}\text { Fruit } \\
\text { weight } \\
(\mathrm{g})\end{array}$ & $\begin{array}{c}\text { Fruit } \\
\text { diameter } \\
(\mathrm{cm})\end{array}$ & $\begin{array}{l}\text { Volume } \\
\text { of fruit } \\
\text { (cc) }\end{array}$ & $\begin{array}{l}\text { Specifi } \\
\text { c } \\
\text { gravity } \\
\left(\mathrm{g} / \mathrm{cm}^{3}\right)\end{array}$ & $\begin{array}{l}\text { Total } \\
\text { yield } \\
\text { per } \\
\text { plant } \\
(\mathrm{kg})\end{array}$ & $\begin{array}{l}\text { Yield } \\
\text { per } \\
\text { square } \\
\text { meter } \\
(\mathrm{kg})\end{array}$ \\
\hline \multicolumn{10}{|l|}{ Spacing (S) } \\
\hline $\mathrm{S}_{1}(45 \times 30 \mathrm{~cm})$ & 12.28 & 3.79 & 46.10 & 80.09 & 10.70 & 84.13 & 0.95 & 3.50 & 15.54 \\
\hline $\mathrm{S}_{2}(45 \times 45 \mathrm{~cm})$ & 15.08 & 5.22 & 76.13 & 93.85 & 11.26 & 97.93 & 0.96 & 6.89 & 20.42 \\
\hline $\mathrm{S}_{3}(45 \times 60 \mathrm{~cm})$ & 16.37 & 5.68 & 90.03 & 98.11 & 12.41 & 102.16 & 0.96 & 9.61 & 21.35 \\
\hline $\mathrm{S}_{4}(60 \times 60 \mathrm{~cm})$ & 18.63 & 6.31 & 112.44 & 106.93 & 11.99 & 110.70 & 0.97 & 12.07 & 20.11 \\
\hline $\mathrm{SEm} \pm$ & 0.167 & 0.136 & 1.003 & 0.308 & 0.106 & 0.399 & 0.003 & 0.104 & 0.228 \\
\hline $\mathrm{CD}$ at $5 \%$ & 0.488 & 0.397 & 2.927 & 0.899 & 0.310 & 1.164 & 0.009 & 0.302 & 0.667 \\
\hline \multicolumn{10}{|l|}{ Training(T) } \\
\hline $\mathrm{T}_{1}$ & 14.94 & 4.95 & 72.15 & 96.91 & 11.67 & 100.52 & 0.96 & 7.14 & 16.97 \\
\hline $\mathrm{T}_{2}$ & 15.89 & 5.50 & 86.59 & 94.84 & 11.65 & 99.18 & 0.96 & 8.43 & 20.13 \\
\hline $\mathrm{T}_{3}$ & 15.93 & 5.30 & 84.78 & 92.48 & 11.46 & 96.49 & 0.96 & 8.48 & 20.96 \\
\hline SEm \pm & 0.145 & 0.118 & 0.868 & 0.267 & 0.092 & 0.345 & 0.003 & 0.090 & 0.198 \\
\hline $\mathrm{CD}$ at $5 \%$ & 0.423 & 0.344 & 2.535 & 0.779 & NS & 1.008 & NS & 0.262 & 0.578 \\
\hline \multicolumn{10}{|c|}{ Interaction $(\mathbf{S} \times \mathbf{T})$} \\
\hline $\mathrm{S}_{1} \mathrm{~T}_{1}$ & 12.53 & 3.10 & 37.65 & 82.11 & 11.50 & 85.04 & 0.97 & 3.15 & 14.00 \\
\hline $\mathrm{S}_{1} \mathrm{~T}_{2}$ & 12.33 & 3.67 & 45.27 & 79.60 & 10.42 & 84.27 & 0.94 & 3.30 & 14.68 \\
\hline $\mathrm{S}_{1} \mathrm{~T}_{3}$ & 11.97 & 4.60 & 55.37 & 78.55 & 10.19 & 83.08 & 0.95 & 4.04 & 17.95 \\
\hline $\mathrm{S}_{2} \mathrm{~T}_{1}$ & 14.03 & 5.03 & 64.93 & 95.52 & 11.25 & 99.35 & 0.96 & 5.49 & 16.25 \\
\hline $\mathrm{S}_{2} \mathrm{~T}_{2}$ & 14.93 & 5.43 & 79.49 & 93.93 & 11.28 & 98.33 & 0.96 & 7.27 & 21.54 \\
\hline $\mathrm{S}_{2} \mathrm{~T}_{3}$ & 16.27 & 5.20 & 83.97 & 92.09 & 11.25 & 96.10 & 0.96 & 7.92 & 23.46 \\
\hline $\mathrm{S}_{3} \mathrm{~T}_{1}$ & 15.83 & 5.17 & 78.28 & 101.67 & 12.09 & 105.43 & 0.96 & 8.02 & 17.82 \\
\hline $\mathrm{S}_{3} \mathrm{~T}_{2}$ & 16.63 & 6.13 & 95.75 & 99.67 & 12.63 & 104.52 & 0.95 & 10.28 & 22.84 \\
\hline $\mathrm{S}_{3} \mathrm{~T}_{3}$ & 16.63 & 5.73 & 96.06 & 93.00 & 12.52 & 96.54 & 0.96 & 10.52 & 23.38 \\
\hline $\mathrm{S}_{4} \mathrm{~T}_{1}$ & 17.37 & 6.50 & 107.73 & 108.33 & 11.83 & 112.28 & 0.96 & 11.89 & 19.80 \\
\hline $\mathrm{S}_{4} \mathrm{~T}_{2}$ & 19.67 & 6.77 & 125.87 & 106.17 & 12.25 & 109.57 & 0.97 & 12.88 & 21.46 \\
\hline $\mathrm{S}_{4} \mathrm{~T}_{3}$ & 18.87 & 5.67 & 103.73 & 106.29 & 11.90 & 110.24 & 0.96 & 11.44 & 19.07 \\
\hline $\mathrm{SEm} \pm$ & 0.290 & 0.236 & 1.737 & 0.533 & 0.184 & 0.690 & 0.005 & 0.179 & 0.396 \\
\hline $\mathrm{CD}$ at $5 \%$ & 0.8456 & 0.6881 & 5.0692 & 1.5571 & 0.5361 & 2.0153 & NS & 0.5237 & 1.1551 \\
\hline
\end{tabular}

The similar findings were reported by Biradar et al., (2014) in capsicum, Harish and Patil (2011) and Sharma et al., (2011) in tomato. Maximum average fruit diameter $(12.41 \mathrm{~cm})$ was observed in wider spacing, $\mathrm{S}_{3}(45 \mathrm{~cm} x$ $60 \mathrm{~cm})$. Similar results were obtained in tomato by Bhahadur and Singh (2005). The highest yield per $\mathrm{m}^{2}(21.35 \mathrm{~kg})$ was obtained in treatment $S_{3}(45 \mathrm{~cm} \times 60 \mathrm{~cm})$ followed by $20.42 \mathrm{~kg}$ per $\mathrm{m}^{2}$ in treatment $\mathrm{S}_{2}(45 \mathrm{~cm} \times 45$ $\mathrm{cm})$. It might be due to effective utilization of land, nutrients and sunlight. The results are in conformity with findings of Mantur and Patil (2008), Dasgan and Abak (2003) and Cebula (1995). The maximum specific gravity (0.97 $\left.\mathrm{g} / \mathrm{cm}^{3}\right)$ and volume of fruit $(110.70 \mathrm{cc})$ were recorded in wider spacing i.e. $\mathrm{S}_{4}(60 \mathrm{~cm} \times 60$ $\mathrm{cm})$. The present results are supported by the findings of Muhammad and Singh (2007) in tomato. 
Among the method of training, the maximum number of clusters per plant (15.93), total yield per plant $(8.48 \mathrm{~kg})$ was observed in $\mathrm{T}_{3}$ (triple stem) and lowest $(7.14 \mathrm{~kg})$ in $\mathrm{T}_{1}$ (single stem), whereas maximum fruit weight (96.91g) in $\mathrm{T}_{1}$ (single stem) this observation was in close conformity with the results of Khoshkam et al., (2014) and Razzak et al., (2013) in tomato and Lal et al., (2014) in capsicum. The maximum number of fruits per plant (86.59) and number of fruits per clusters (5.50) was observed in $\mathrm{T}_{2}$ (double stem), these findings of the present investigation are in conformity with findings of Dasgan and Abak (2003) in bell peppers. The fruit diameter and specific gravity showed nonsignificance results. But the volume of fruit was significantly affected by training level with maximum volume of fruit $(100.52 \mathrm{cc})$ in $\mathrm{T}_{1}$ (single stem). The present results are supported by the findings of Muhammad and Singh et al., (2007) in tomato. Maximum yield per square meter $(20.96 \mathrm{~kg})$ was observed in $\mathrm{T}_{3}$ (triple stem), which was at par with $\mathrm{T}_{2}$ (double stem). The present results are supported by the finding of Mazed et al., (2015) and Alsadon et al., (2013) in tomato. Among all the treatment combinations, $\mathrm{S}_{4} \mathrm{~T}_{2}$ $(60 \mathrm{~cm} \times 60 \mathrm{~cm}$ and double stem) showed maximum number of clusters per plant (19.67), number of fruits per cluster (6.77) and total yield per plant $(12.88 \mathrm{~kg})$, while $\mathrm{S}_{4} \mathrm{~T}_{1}(60 \mathrm{~cm} \times 60 \mathrm{~cm}$ and single stem) showed maximum fruit weight $(108.33 \mathrm{~g})$ and maximum fruit diameter $(12.63 \mathrm{~cm})$ was reported in $S_{3} T_{2}(60 \mathrm{~cm} \times 45 \mathrm{~cm}$ and double stem). Similar results were also recorded by Mantur and Patil (2008) in tomato, Dasgan and Abak (2003) in peppers, Lal et al., (2014) in capsicum, Charlo et al., (2007) in cherry tomato, Ara et al., (2007) in indeterminate tomato. Maximum number of fruits per plant (125.87) was noticed in $\mathrm{S}_{4} \mathrm{~T}_{2}(60 \mathrm{~cm} \times 60 \mathrm{~cm}$ and double stem) treatment combination and minimum (37.65) in $\mathrm{S}_{1} \mathrm{~T}_{1}(45 \mathrm{~cm} \times 30 \mathrm{~cm}$ and single stem) treatment combination. Similar results were reported by Kumar and Chandra (2014) in capsicum. The maximum volume of fruit $(112.28 \mathrm{cc})$ observed in $\mathrm{S}_{4} \mathrm{~T}_{1}(60 \mathrm{~cm} \times 60$ $\mathrm{cm}$ and single stem) treatment combination. Similar finding was quoted by Ameta et al., (2014) in capsicum. The maximum yield per square meter $\left(23.46 \mathrm{~kg}\right.$ ) was recorded in $\mathrm{S}_{2} \mathrm{~T}_{3}$ (45 cm x $45 \mathrm{~cm}$ and triple stem), this trend of interaction effect was also reported by Maniutiu et al., (2010).

\section{References}

Alsadon, A., Wahb-Allah, M., Abdel-Razzak, H. and Ibrahim, A. 2013. Effects of pruning systems on growth fruit yield and quality traits of three greenhousegrown bell pepper (Capsicum annuum L.) cultivars. Australian J. Crop Sci., 7(9): 1309-1316.

Ameta, K.D., Kaushik, R.A., Dubey, R.B. and Pareek, S. 2014. Effect of training and crop geometry on yield attributes and yield of poly house grown "Natasha"red capsicum. Int. J. Innovative Horticulture, 3(1): 67-70.

Anonymous. 2014. www.nhb.gov.in, Indian Horticulture database 2014. pp 4-181.

Ara, N., Bashar, M.K., Begum, S. and Kakon, S.S. 2007. Effect of spacing and stem pruning on the growth and yield of tomato. Int. J. Sustainable Crop Production, 2(3): 35-39.

Bahadur, A. and Singh, K.P. 2005. Optimization of spacing and drip irrigation scheduling in indeterminate tomato (Lycopersicon esculentum Mill.). Indian J. Agri. Sci., 75(9): 563565.

Bhattarai, P., Kaushik, R.A., Ameta, K.D., Jain, H.K., Kaushik, M.K. and Sharma, F.L. 2015. Effect of plant geometry and fertigation on growth and yield of cherry tomato (Solanum lycopersicon var. cerasiforme) under zero energy 
poly house conditions. Indian $J$. Horticulture, 72(2): 297-301.

Biradar, M.S., Patil, A.A., Mantur, S. M. and Mannikeri, I.M. 2014. Influence of growing environment and planting geometry on yield and yield attributes of capsicum (Capsicum annuum L.var. grossum Sendt.) genotypes. Karnataka J. Agri. Sci., 27(2): 202-207.

Cebula, S. 1995. Optimization of plant and shoot spacing in greenhouse production of sweet pepper. Acta Horticulturae, 412(2): 321- 328.

Charlo, H.C.O., Castoldi, R., Ito, L.A., Fernandes, C. and Braz, L.T. 2007. Productivity of Cherry tomatoes under protected cultivation carried out with different types of pruning and spacing. Acta Horticulture, page 323 - 326.

Dasgan, H.Y. and Abak, K. 2003. Effects of plant density and number of shoots on yield and fruit characteristics of peppers grown in glasshouses. Turkey J. Agri., 27: 29-35

Harish, S. and Patil, B.N. 2011. Investigations on growing condition, spacing and calcium sprays on seed yield, quality and storability of tomato (Solanum lycopersicum L.) Seeds M.Sc. (Agri.) Thesis. University of Agricultural Sciences, Dharwad.

Hesami, A., Khorami, S.S. and Hosseini, S. S. 2012. Effect of shoot pruning and flower thinning on quality and quantity of semi-determinate tomato (Lycopersicon esculentum mill.). Notulae Scientia Biologicae, 4(1): 108111.

Jovicich, E., Cantliffe D.J. and Hochmuth, G.J. 1998. Plant density and shoot pruning on yield and quality of a summer greenhouse sweet pepper crop in north-central Florida.

Khoshkam, S., Seyedi, Z. and Ahmad, A. 2014. The impact of different plant training systems on quantitative and qualitative parameters of greenhouse tomato cultivars. Int. J. Farming and Allied Sci., 3(6): 659-663.

Kumar, U. and Chandra G. 2014. Effect of spacing and training levels on growth and yield of capsicum under polyhouse in North Bihar conditions. J. Hill Agri., 5(1): 9-12.

Lal, M., Kanwar, H.S. and Kanwar, R. 2014. Impact of spacing and training on seed yield of capsicum, (Capsicum annиum L.) under protected conditions. Int. J. Farm Sci., 4(3): 42-48.

Maniutiu, D., Sima, R., Apahidean, A.S. Pahideana, M. and Ficior, D. 2010. The influence of plant density and shoot pruning on yield of bell pepper cultivated in plastic tunnel. Bull. UASVM Horticulture, 67(1): 259-263.

Mantur, S.M. and Patil, S.R. 2008. Influence of spacing and pruning on yield of tomato grown under shade house. Karnataka J. Agri. Sci., 21(1):,97-98.

Mazed, H.E.M.K., Akand, H., Haque, N., Pulok, A.I. and Partho, S.G. 2015. Yield and economic analysis of tomato (Lycopersicon esculentum Mill) as influenced by potassium and stem pruning. Int. J. Scientific and Res. Publications, 5(1): 1-5.

Mishra, G.P., Singh, N., Kumar, H. and Singh, S.B. 2010. Protected cultivation for food and nutritional security at Ladakh. J. Defense Sci., 61(2): 219-225.

Muhammad, A. and Singh, A. 2007. Intrarow spacing and pruning effect on fresh tomato yield in Sudan Savanna of Nigeria. J. Plant Sci., 2(2): 153-161.

Raiola, A., Ragino, M.M., Calafior, R., Frusciante, L. and Barone, A. 2014. Enhancing the human promoting effects of tomato fruit fortified food. Corporation Mediators of inflammation. doi:10.1155/2014/139873.

Rajendra, B.N., Patil, S.R., Swamy, K.M. and Anasubai, G.H. 2013. Impact of 
different spacing on growth and yield of indeterminate tomato grown under shade house. The Asian J. Horticulture, 8(1): 377-378.

Razzak, H.A., Ibrahim, A., Allaha, M. W. and Alasadon, A. 2013. Response of cherry tomato (Solanum lycopersicum var. cerasiforme) to pruning system and irrigation rates under green house condition. Asian J. crop sci., page 1-11.

Sainju, M.U., Dris, R. and Singh, B. 2003. Mineral nutrition of tomato. Food Agri. Environ., 1(2): 176-183.

Sharma, A., Kaushik, R.A., Sarolia, D.K. and Sharma, R.P. 2011. Response of cultivars, plant geometry and methods of fertilizer application on parthenocarpic cucumber (Cucumis sativus L.) under zero energy polyhouse condition during rainy season. Veg. Sci., 37(2): 184-186.

Singh, B. and Kumar, M. 2005. Effect of plant spacing and stem pruning on growth and yield of cherry tomato in greenhouse. Haryana J. Horticultural Sci., 34(1/2): 179-180.

Wu, Z., Sun, S., Wang, F. and Guo, D. 2011. Establishment of regeneration and transformation system of tomato (Lycopersicon esculentum Mill.). $J$. Biotechnol., 3 (1): 53-60.

\section{How to cite this article:}

Satveer Yadav, K.D. Ameta, S.K. Sharma, R.B. Dubey, R.S. Rathore, Hareram Kumar and V.K. Kapuriya. 2017. Effect of Spacing and Training on Vegetative Growth Characteristics and Yield of Tomato (Solanum lycopersicum L.) Grown in Polyhouse. Int.J.Curr.Microbiol.App.Sci. 6(5): 1969-1976. doi: https://doi.org/10.20546/ijcmas.2017.605.220 